\title{
Guidelines on sampling intensity of bees (Hymenoptera: Apoidea: Apiformes)
}

\author{
Józef Banaszak • Weronika Banaszak-Cibicka • \\ Piotr Szefer
}

Received: 5 September 2013/Accepted: 16 July 2014/Published online: 26 July 2014

(C) The Author(s) 2014. This article is published with open access at Springerlink.com

\begin{abstract}
Changes in bee fauna, such as the disappearance of certain species or increasing abundance of others, are very important. The common belief that pollinating insects are facing problems also prompts detailed studies of the bee fauna in order to track on-going changes. Assessment of the state of bee communities in particular ecosystems or ecosystem complexes within a landscape, tracing the course of trends in fauna and also predicting their future structures resulting from current changes, are only possible if sampling is carried out at an appropriate frequency, so that representative materials are obtained. The aim of the present study was to determine what sampling intensity during the growing season would enable the collection of representative materials to evaluate species diversity of bees in a study area. Repeated bee sampling at monthly intervals throughout the period of activity of bees resulted in the identification of 73 bee species, corresponding to $51.4 \%$ of the estimated number of bee species in the study area. When samples were obtained twice a month, 93 bee species were captured, accounting for $65.5 \%$ of the estimated number of bee species. When sampling took place nearly four times a month, 108 bee species were captured, making up $76 \%$ of the estimated number of bee species; the materials obtained at this sampling rate may be regarded as representative. The importance of accounting for the phenology of a given animal group during a sampling effort is also emphasised.
\end{abstract}

\footnotetext{
J. Banaszak · P. Szefer

Institute of Environmental Biology, Kazimierz Wielki

University, Ossolińskich 12, 85-093 Bydgoszcz, Poland

W. Banaszak-Cibicka $(\bowtie)$

Institute of Zoology, Poznań University of Life Sciences,

Wojska Polskiego 71C, 60-625 Poznań, Poland

e-mail: banaszak@up.poznan.pl
}

Keywords Hymenoptera $\cdot$ Apoidea $\cdot$ Bees . Sampling effort

\section{Introduction}

Species richness is the most commonly used measure of biological diversity in ecology and conservation; therefore, estimating species richness is of crucial importance for the conservation and management of biodiversity (Boulinier et al. 1998; Colwell and Coddington 1994). Data on species number in different areas are used in comparative studies that serve to draw conclusions regarding faunal richness. Whether these conclusions are correct depends on both the representativeness of the samples and their comparability. These parameters, in turn, are a function of the quantity of samples collected, the use of specific sampling methods and the choice of a particular sampling period.

Pollinators are often considered crucial species in ecosystems (Kearns and Inouye 1997). At our latitude, bees (Hymenoptera: Apiformes) are the most important pollinators. Bees are exceptional among animals: completely dependent on flowers for food, they are the most important vectors of cross-pollination in plants. Unlike the other Aculeata, bee larvae are exclusively fed a mixture of nectar and pollen or the secretion of hypopharyngeal glands, known as royal jelly. The importance of bees needs to be viewed in terms of their role as pollinators of crops, let alone their role in the ecosystem. All the more alarmingly, there is current evidence of disappearance of rare species outside their continuous ranges. Faunal analyses have revealed that at least $3.3 \%$ Apoidea species have become extinct in Poland over the last half-century and at least a further $8 \%$ may have perished as well (Banaszak et al. 2000; Banaszak 2009, 2010). Pollinator counts have also been falling in Western 
Europe (O’Toole 1993; Biesmeijer et al. 2006; Fitzpatrick et al. 2007). At the same time, the expansion of some species, which have increased their abundance and/or extended their ranges, has also been described (Pekkarinen et al. 2000). However, available data are still insufficient to assess the rate and magnitude of changes in bees' natural resources. Answering these vital questions requires the availability of reliable documentation of the state of the fauna.

Just like nature conservation in general, the protection of threatened and useful insects should be based on the comprehensive determination of their multifaceted characteristics. Any losses that have occurred may only be assessed against a complete inventory of species.

In spite of its importance, ecologists have not always appreciated the effects of sampling effort on richness measures and comparisons. Many authors draw conclusions based on materials obtained from an insufficient number of samples or, equally importantly, collected only at particular times within the growing season. In Poland, bees are active for over 6 months, from late March to midOctober. Depending on latitude and altitude, this period can be shorter or longer (Banaszak 1993).

With the growing interest in pollinator conservation, a need has emerged for a simple, unbiased method to sample local bee faunas reliably. The major aim of the present study was to determine a reliable sampling frequency during the growing season to enable the collection of representative samples allowing evaluation of bee species diversity in a study area. An additional objective was to describe the relationship between sampling frequency and recorded diversity of bees.

\section{Materials and methods}

Study area

The study was carried out in the Notec River valley in the Kujawy-Pomerania region, and more specifically, in the village of Małe Rudy near Bydgoszcz, Poland. The study site is a small island of xerothermic vegetation, situated between the Noteć and the Bydgoszcz Canal and surrounded by mesic meadows. It is $120 \mathrm{~m}$ wide and $500 \mathrm{~m}$ long and has a total area of approx. 6 ha. A detailed description of the study area, with an evaluation of the plant cover, can be found in Krasicka-Korczyńska and Korczyński (2003) and Banaszak et al. (2014).

\section{Bee sampling}

Bees were collected in 2004, 2005 and 2007. In the first year of the study, the site was visited only in August and September (every 2 weeks). In 2005 and 2007, field trips were conducted throughout the growing season, i.e. from March or April to September, usually at weekly intervals
(18 trips in 2005, 25 trips in 2007). Bees were captured into an insect net under conditions favouring their activity $\left(>20{ }^{\circ} \mathrm{C}\right)$. An investigator would walk randomly within the study site over a set period $(1.5 \mathrm{~h})$ and use an insect net to capture any bees he/she saw. Protected species, such as bumblebees, were not captured, while those present in very large numbers, mostly colony-forming species, were caught on a limited scale. The captured individuals were subsequently identified to species in the laboratory.

For the phenological analyses of bee communities, the division proposed by Banaszak (1989) was used. This division distinguishes three phenological periods in bee activity in the Central Polish Lowlands: spring (late March-early June), spring-summer transition (mid-Juneearly July) and summer (mid-July-end of growing season).

\section{Data analysis}

The actual number of species that could be identified within the site was calculated using the Chao 2 simple estimator (Chao 1984). The estimator is based on the number of species noted only in one sample (uniques) or two samples (duplicates). The estimator works well for data where most species diversity information is concentrated in low-frequency classes, e.g. in collections with a predominance of rare species. Information on the number of undetected species in a collection allows determination of the degree of representativeness of the materials and its informative value. A procedure proposed by Chao et al. (2009) serves to estimate how many samples/individuals need to be captured to yield the total number of species estimated for a collection. Spreadsheet makro supplemented by Chao et al. (2009) was used to construct a species accumulation curve (Gotelli and Colwell 2001) and calculate the number of samples or individuals that need to be collected to ensure 95 and $100 \%$ representativeness of the collection.

The material, comprising 45 samples collected at a rate of four times per month, was divided into two subsets to simulate different sampling frequencies: 24 samples collected twice a month and 12 samples collected once a month. The number of species identified, Chao2-estimated number of species and the analytical estimator of rarefaction curves MaoTau were calculated for both subsets using EstimateS software (Colwell 2013).

\section{Results}

Sampling effort necessary for detecting 95 and $100 \%$ of all species

We collected a total of 1,244 individuals of 108 species. The species accumulation curve (Fig. 1) was still rising at 
Fig. 1 Expected cumulative species number as a function of the number of individuals/ samples collected. The graph shows the number of samples/ individuals necessary to identify 95 and $100 \%$ of the Chao2estimated species richness

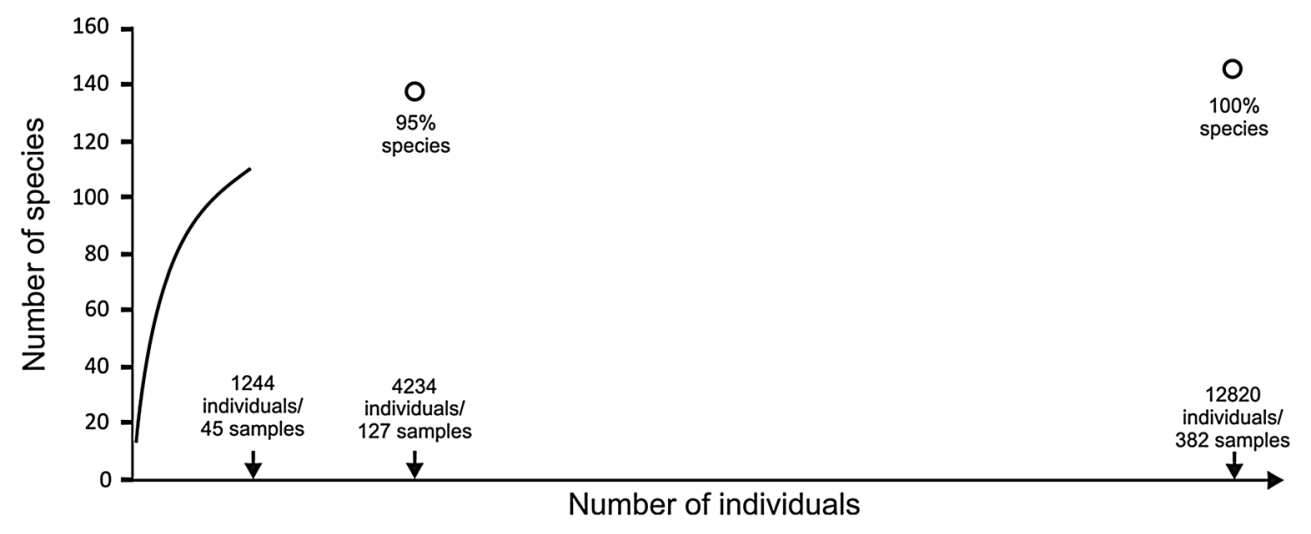

Table 1 Percentage estimates for the 45 samples collected in 2005 and 2007 and for different sampling frequencies in comparison to the estimated total species number

\begin{tabular}{llll}
\hline $\begin{array}{l}\text { Sampling } \\
\text { frequency } \\
(2005+2007)\end{array}$ & $\begin{array}{l}\text { Species } \\
\text { richness } \\
(\text { S) }\end{array}$ & $\begin{array}{l}\text { \% of recorded } \\
\text { number of } \\
\text { species }\end{array}$ & $\begin{array}{l}\% \text { of estimated } \\
\text { number of } \\
\text { species }\end{array}$ \\
\hline (45) nearly weekly & 108 & 100 & 76 \\
(24) $2 \times$ monthly & 93 & 86.1 & 65.5 \\
(12) $1 \times$ monthly & 73 & 67.5 & 51.4 \\
\hline
\end{tabular}

Maximum number of recorded species $=108$; estimated number of species $=142$

1,244 individuals collected, which means that it was not the total species number that could be expected. The expected species richness based on the Chao2 estimator was 142 (95\% CI 121, 195). Thus the actual species number at the study site accounted for $76 \%$ of that value. The slope of the curve suggests a relatively high diversity and evenness of the site.

Bee sampling conducted once a month (12 samples) throughout the period of activity of bees yielded 73 bee species, accounting for $51.4 \%$ of the estimated number of bee species in the study area. Twice-monthly sampling ( 24 samples) yielded 93 bee species, or $65.5 \%$ of the estimated bee species number. Finally, sampling at a frequency of nearly four times a month (45 samples) yielded 108 bee species, or $76 \%$ of the estimated total number (Table 1; Fig. 2). The samples collected over 2 years were also analysed with regard to the number of species recorded in individual seasons in order to determine the average contribution of one season to the estimated total number of species. The following percentages of the total estimated species number were obtained in the years 2005 and 2007, respectively: 61.4 and $53.1 \%$ (mean: $57.2 \%$ ) for the sampling frequency of four times a month; 51.0 and $43.4 \%$ (mean: $42.7 \%$ ) for twice-monthly sampling; and 42.1 and $30.3 \%$ (mean: 36.2 ) for monthly sampling. None

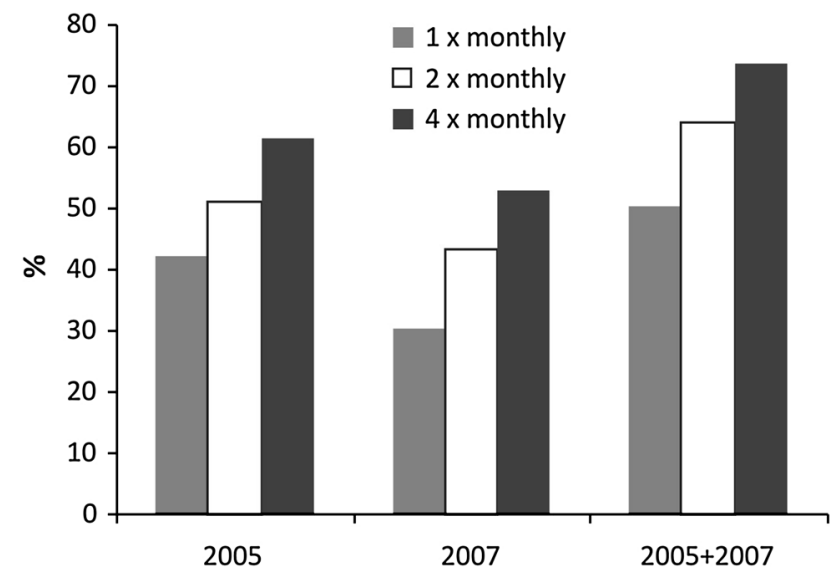

Fig. 2 Number of species identified as percentages of estimated number of species

of these values of the number of individuals or species ensured a satisfactory degree of representativeness.

These results show that in order to identify $95 \%$ of all species, 2,990 more individuals or 83 additional samples would need to be collected. In order to identify all species present in the study area, 11,576 more individuals or 337 more samples should be collected (Fig. 1). However, such a high sampling effort would certainly have a negative effect on the local bee communities.

\section{Phenological adjustment to determining sampling times}

An insight into the phenology of the animal group of interest is also vital in sampling. In the case of bees, early spring (from mid-April to mid-May) and summer (July and early August) are particularly important as these are the times of the highest species diversity among bees. Accordingly, increased sampling frequency in these two periods, when bee communities are richest in species and individuals, will result in capturing a higher number of species (Figs. 3, 4). 
Fig. 3 Phenology of appearance of wild bees (mean number of species and individuals per sample) during sampling in 2005 and 2007 separately
Fig. 4 Phenology of appearance of wild bees (mean number of species and individuals per sample) during sampling in 2005 and 2007 together
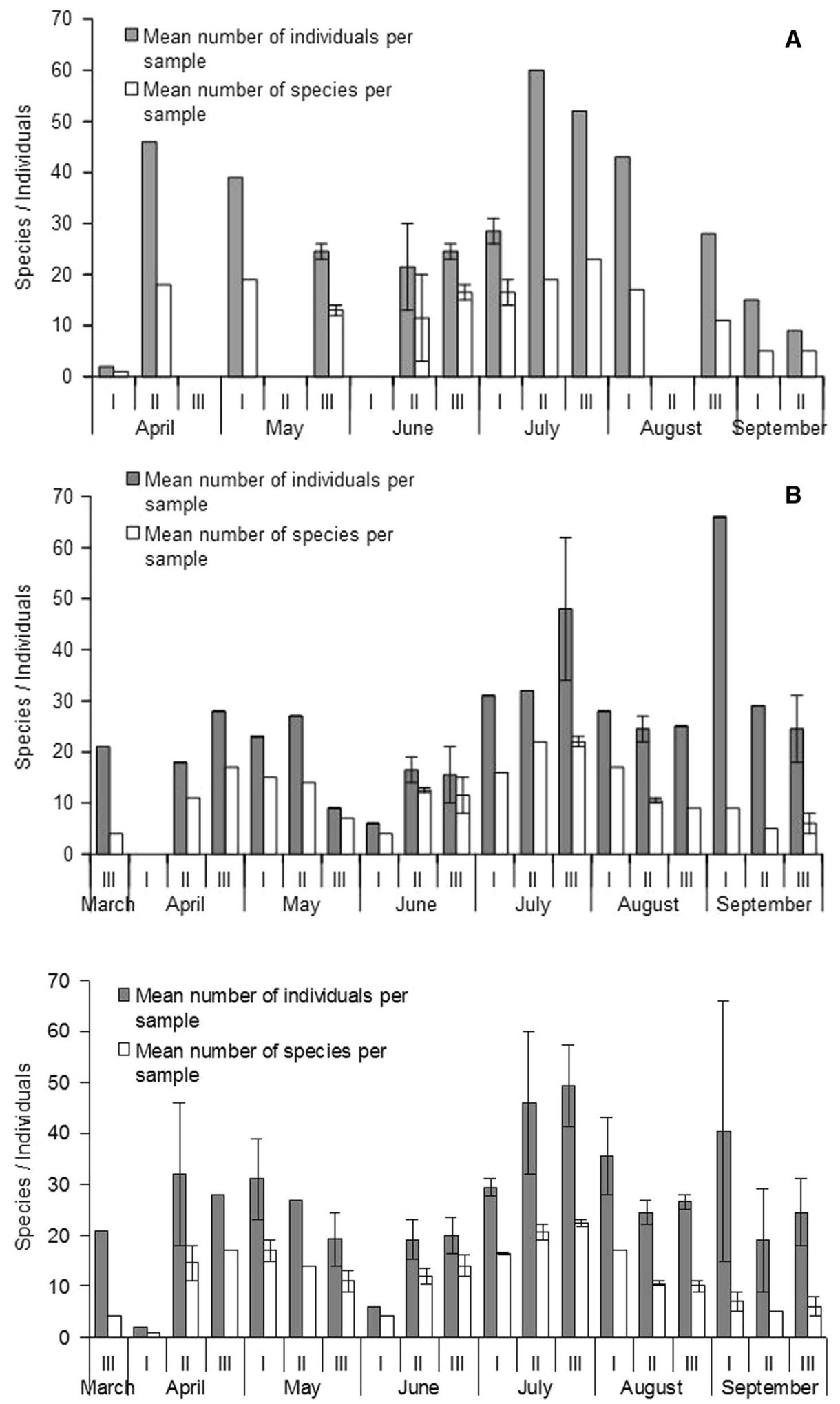

\section{Discussion}

As expected, increasing the sample size results in collection of a greater proportion of the community. Our study shows that the identification of all bee species inhabiting a study area is very difficult, time-consuming and uneconomical in practice. This seems to be the general pattern in entomological studies (Żmihorski et al. 2012; Novotny and 
Basset 2000; Chao et al. 2009). However, sampling at a frequency of nearly four times a month yielded 108 bee species, i.e. $76 \%$ of the estimated species number (Fig. 2) and such a sample can be considered representative. In faunal studies of Apoidea, representativeness of a collection rarely exceeds $70 \%$ (Williams et al. 2001).

Thus the present study demonstrates that the collection of representative material would require bee sampling from late March to September every 7-10 days. This level of sampling frequency should be maintained particularly in spring (from April to mid-May) and in July, when bee diversity and density reach a peak. Bee fauna is subject to change during the growing season. Early bees appear in late March or early April. The successive appearance and co-occurrence of particular species following changes in plant communities is a sign of seasonality of bee occurrence. Two distinct seasons-spring and summer-are separated by a transitory spring-summer period (mid-Juneearly July), when bee density and diversity are lower. The richest season is summer, with a peak starting in mid-July (Banaszak 1989). A high degree of trophic specialisation of certain species or higher taxa means that their appearance is related to the blooming of relevant bee forage plants. As a result, differences in timing of appearance are seen even at the family level (Banaszak 1993). The beginning of the flight season of oligotrophic species, which feed on the flowers of related species, coincides with the blooming of these host plants and ends when their blooming is over (Linsley 1958).

High-frequency sampling throughout the growing season is particularly important for the identification of rare species that are present in low numbers or are active over short periods. There is little likelihood that such species can be found when sampling is conducted once a month or even less frequently. Considering the duration of the flight period, bee species may be divided into a number of categories: (1) species with short periods of activity (approx. 1.5-2 months) in various parts of the growing season in the spring or summer; (2) species present for most of the growing season or during the entire period from spring to autumn (mainly social species); and (3) species occurring in two generations, such as many Andrena and Nomada (Banaszak 1993). Thus, a sampling effort excluding April, for example, would yield a species list with many spring species missing.

Research on the fauna of an area should also be conducted over at least two growing seasons. Individual years may differ in, for example, weather conditions, which may affect the occurrence of bees. The pattern of appearance of some species is also irregular over the years, with massive appearance in 1 year and sporadic presence in another (Banaszak et al. in press). Two-year sampling increases the probability of recording such species.
Changes in bee fauna, such as the disappearance of certain species or increasing abundance of others, are very important at present. The apidological (mellitological) literature contains many works on faunal changes (e.g. Collins 1987; Collins and Weels 1987; Gauld et al. 1990; Day 1991; O’Toole 1993, 1994; Williams 1982, 1986; Rasmont et al. 1993; Pekkarinen 1999; Banaszak 1997, 2005, 2010; Banaszak et al. 2003; Goulson et al. 2005, 2008). The common belief that pollinating insects are facing problems (Allen-Wardell et al. 1998; Kearns et al. 1998) also prompts detailed studies of the bee fauna in order to track on-going changes. Comparisons of data from one study with findings from other areas and other periods are reliable only if sampling is carried out at an appropriate frequency, so that representative materials are obtained. Published studies vary considerably in duration, collecting intensity, and protocol. Nowadays we can find many studies where sampling is conducted once a month or even less frequently and for one season only (Mandelik et al. 2012). In case of other studies when we have only information about the sampling intensity we may only speculate about the impact of sampling intensity on the number of bee species recorded from the study area. According to our researches the rare species that are present in low numbers or are active over short periods are most likely missing in the collected material. What is more we cannot be sure how to explain the lack of those species-as the absence of those species in the study area or the absence in our material only. That is why data from fragmentary studies cannot serve as a basis for further faunal research. Moreover, they may lead to erroneous conclusions, underestimating species diversity in the study area.

The methods always depend on the aim of a study. More limited sampling, not aimed at achieving a complete species list for a site, can be useful in a comparative study though. In this case we should remember about the standardising the sampling techniques during the study. However, even in comparative studies, bee sampling should be conducted at least once a month throughout the period of bees activity.

\section{Conclusion}

In faunal studies the collection of representative material would require bee sampling from late March to September every 7-10 days. This level of sampling frequency should be maintained particularly in spring (ranging between April and mid-May) and in July, when bee diversity and density reach their peak.

In comparative, ecological studies we recommend that bee sampling should be conducted at least once a month from April to August. 
Open Access This article is distributed under the terms of the Creative Commons Attribution License which permits any use, distribution, and reproduction in any medium, provided the original author(s) and the source are credited.

\section{References}

Allen-Wardell GP, Bernhardt R, Bitner A, Burquez SL, Buchmann JH et al (1998) The potential consequences of pollinator declines on the conservation of biodiversity and stability of food crop yields. Conserv Biol 12:8-17

Banaszak J (1989) Fenologia pszczół (Hymenoptera, Apoidea) Nizin Środkowopolskich. Bad Fizjogr Pol Zach C Zool 38:123-136

Banaszak J (1993) Ekologia pszczół. PWN. Warszawa-Poznań, 263 ss

Banaszak J (1997) Local changes in the population of wild bees. I. Changes in the fauna 10 years later. Ochr Przyr 54:119-130

Banaszak J (2009) Pollinating insects (Hymenoptera: Apoidea, Apiformes) as an example of changes in fauna. Fragm Faun 52(2):105-123

Banaszak J (2010) The persistence of and changes in a bee fauna over the last century: case of Wielkopolska-Kujawy Lowland in western Poland (Hymenoptera: Apoidea, Apiformes). Pol J Entomol 79:367-409

Banaszak J, Czechowska W, Czechowski W, Garbarczyk H, Sawoniewicz J, Wiśniowski B (2000) Threats and perspectives of protection of Hymenoptera. Wiad Entomol 18(2):177-211

Banaszak J, Cierzniak T, Ratynska H (2003) Local changes in populations of wild bees (Hymenoptera: Apoidea): 20 years later. Pol J Entomol 72:261-282

Banaszak J, Ratyńska H, Szefer P (2014) Diversity of bees and associated plant cover. The case of "Ostrów Małe Rudy" habitat island in the Noteć River valley near Bydgoszcz (Hymenoptera, Apoidea, Apiformes). Bad Fizjograf C54:29-56

Banaszak WA (2005) What has caused the decline of the solitary bee Anthophora plagiata (Illiger, 1806) (Hymenoptera: Apoidea) in the Wielkopolska-Kujawy Lowland in west Poland? Pol J Entomol 74:157-185

Biesmeijer JC, Roberts SPM, Reemer M, Ohlemuller R, Edwards M, Peeters T et al (2006) Parallel declines in pollinators and insectpollinated plants in Britain and the Netherlands. Science 313:351-354

Boulinier T, Nichols JD, Sauer JR, Hines JE, Pollock KH (1998) Estimating species richness: the importance of heterogeneity in species detectability. Ecology 79:1018-1028

Chao A (1984) Nonparametric estimation of the number of classes in a population. Scand J Stat 11:265-270. doi:10.2307/4615964

Chao A, Colwell RK, Lin CW, Gotelli NJ (2009) Sufficient sampling for asymptotic minimum species richness estimators. Ecology 90:1125-1133

Collins NM (1987) Legislation to conserve insects in Europe. Amat Entomol Soc 13:1-80

Collins NM, Weels SM (1987) Invertebrates in need of special protection in Europe. Nature and Environment Series 35. Council of Europe, Strasburg

Colwell RK (2013) EstimateS: statistical estimation of species richness and shared species from samples. Version 9 and earlier. User's Guide and application. viceroy.eeb.uconn.edu/estimates/ index.html

Colwell RK, Coddington JA (1994) Estimating terrestrial biodiversity through extrapolation. Philos Trans R Soc B 345:101-118
Day MC (1991) Towards the conservation of aculeate Hymenoptera in Europe. Nature and Environment Series, Council of Europe, Strasburg

Fitzpatrick Ú, Murray TE, Paxton RJ, Breen J, Cotton D, Santorum V et al (2007) Rarity and decline in bumblebees - a test of causes and correlates in the Irish fauna. Biol Conserv 136:185-194

Gauld ID, Collins N, Fitton MG (1990) L'importance biologique et la conservation des hymenopteres en Europe. Council of Europe, Strasburg

Gotelli N, Colwell RK (2001) Quantifying biodiversity: procedures and pitfalls in the measurement and comparison of species richness. Ecol Lett 4:379-391

Goulson D, Hanley ME, Darvill B, Ellis JS, Knight ME (2005) Causes of rarity in bumblebees. Biol Conserv 122:1-8

Goulson D, Lye GC, Darvill B (2008) Decline and conservation of bumble bees. Ann Rev Entomol 53:191-208

Kearns CA, Inouye DW (1997) Pollinators, flowering plants, and conservation biology. Bioscience 47:297-307

Kearns CA, Inouye DW, Waser NM (1998) Endangered mutualisms: the conservation of plant-pollinator interactions. Ann Rev Ecol Syst 29:83-112

Krasicka-Korczyńska E, Korczyński M (2003) "Ostrów Małe Rudy" w dolinie Noteci. In: Krasicka-Korczyńska E (ed) Flora i Fauna Pomorza i Kujaw. Wydawnictwa uczelniane Akademii Techniczno-Rolniczej, Bydgoszcz, pp 105-114

Linsley EG (1958) The ecology of solitary bees. Hilgardia 27(19):543-599

Mandelik Y, Winfree R, Neeson T, Cremen C (2012) Complementary habitat use by wild bees in agro-natural landscapes. Ecol Appl 22(5):1535-1546

Novotny V, Basset Y (2000) Rare species in communities of tropical insect herbivores: pondering the mystery of singletons. Oikos 89:564-572

O'Toole C (1993) Diversity of native bees and agroecosystems. In: La Salle J, Gauld ID (eds) Hymenoptera and biodiversity. Natural History Museum London and CAB International, Wallingford, pp 169-196

O'Toole C (1994) Who cares for solitary bees? In: Matheson A (ed) Forage for bees in an agricultural landscape. International Bee Research Association, Cardif, pp 47-55

Pekkarinen A (1999) Oligolectic bee species and their decline in Finland (Hymenoptera: Apoidea). In: Elberg K, Martin M, Pekkarinen A (eds) Proceedings of the 24th nordic congress of entomology, Tartu, pp 151-156

Pekkarinen A, Pitkänen M, Söderman G (2000) Insect pollinators. In: Pitkänen M, Tiainen $\mathrm{J}$ (eds) Biodiversity of agricultural landscapes in Finland. Birdlife Finland Conservation Series, pp 69-80

Rasmont P, Leclerco J, Jacob-Remacle A, Pauly A, Gaspar Ch (1993) The faunistic drift of Apoidea in Belgium. In: Bruneau E (ed) Bees for pollination. Commission of the European Communities, Brussels, pp 65-87

Williams PH (1982) The distribution and decline of British bumble bees (Bombus Latr.). J Apic Res 21(4):236-245

Williams PH (1986) Environmental change and the distributions of British bumble bees (Bombus Latr.). Bee World 67(2):50-61

Williams NM, Minckley R, Silviera F (2001) Variation in native bee faunas and its implications for detecting community changes. Conserv Ecol 5(1):7

Żmihorski M, Sienkiewicz P, Tryjanowski P (2012) Never ending story: a lesson in using sampling efficiency methods with ground beetles. J Insect Conserv. doi:10.1007/s10841-012-9514-Z 